\title{
Mixed reproduction systems in Opuntia monacantha (Cactaceae) in Southern Brazil
}

\author{
MAURÍCIO LENZI ${ }^{1,2}$ and AFONSO INÁCIO ORTH ${ }^{1}$
}

(received: October 19, 2011; accepted: February 22, 2012)

\begin{abstract}
Mixed reproduction systems in Opuntia monacantha (Cactaceae) in Southern Brazil). The Cactaceae have morphological and physiological adaptations associated with their life histories that are reflected in different modes of reproduction and multiplication. The reproductive phenology, preferential reproductive mode, and the sexual and asexual multiplication of Opuntia monacantha were investigated between 2003 and 2006 in two restinga (sandy coastal) environment in Southern Brazil to determine the adaptive values of its reproduction modes. Flowering was annual and occurred continuous for approximately 100 days between the months of September and January, with a few flowers opening per day per individual (but many in the whole population). Facultative xenogamy was identified as the preferential sexual system, with the highest levels of fruit and seed formation following natural pollination. The seeds are recalcitrant and have high germinative capacities under laboratory conditions. Seedling recruitment and establishment in the field was extremely reduced. The skins of the fruits and the cladodes have high capacities for regeneration and clonal multiplication because of their areolas.
\end{abstract}

Key words - cacti, clonal multiplication, reproductive biology, restinga vegetation

\section{INTRODUCTION}

Restinga areas are nearshore marine and continental deposits laid down during the Holocene era during cycles of marine regression and transgression (Araújo \& Lacerda 1987, Suguio 2003), and are generically considered coastal plains. The term restinga has also been used to designate various vegetation formations that occur on these coastal sites, including beach and pre-dune areas, sand dunes, and low sections between the internal dunes and inland lake margins (Araújo \& Lacerda 1987). Restinga vegetation is notable for its tolerance to high salt levels, dry sandy soils, and high levels of solar radiation - and these plants have fundamental roles in stabilizing coastal sediments and maintaining natural drainage patterns (Falkenberg 1999, Scherer et al. 2005).

The family Cactaceae comprises species with morphological, physiological, and ecological adaptations to extreme environments (Osborn et al. 1988, Mandujano et al. 1998a, Negrón-Ortiz 1998, Soffiatti \& Angyalossy 2003) as, for example, the capacity to store large quantities of water in their stems, the absence of leaves, the presence of spines, and CAM metabolism (Mandujano et al. 1998a). Among the Cactaceae, species of the genus Opuntia Mill. (Opuntioideae) generally demonstrate morphological characteristics that include

\footnotetext{
1. Universidade Federal de Santa Catarina, Departamento de Fitotecnia, Centro de Ciências Agrárias, PPG - Recursos Genéticos Vegetais, Caixa Postal 476, 88040-900 Florianópolis, SC, Brazil

2. Corresponding author: mlenzi34@hotmail.com
}

the presence of areolas with hairs and spines, a succulent stem modified to a cladode with a green epidermis, the lack of large leaves, and the production of fleshy fruits that are simple berries (Scheinvar 1985). The genus Opuntia is represented in Brazil by more than 150 species (Taylor \& Zappi 2004), and the individuals of this group are commonly known as "opúntias" or "palmas-forrageiras". Scheinvar (1985) identified two species of wild Opuntia cactus $(O$. dillenii var. reitzii Scheinvar and $O$. monacantha (Willd.) Haw.) exclusive to resting a vegetation in the state of Santa Catarina, in Southern Brazil.

The phenological patterns, reproductive systems, and methods of multiplication of the Opuntia are directly associated with the environments they occupy (Scheinvar 1985, Mandujano et al. 1997). The initiation of the differentiation of areolas into floral buds principally occurs during the spring after the colder winter in subtropical regions, a period marked by increasing temperatures and day light hours (September/October) (Nerd \& Mizrahi 1997, 2001), and the Opuntia can simultaneously initiate the differentiation of areolas, flowers, and young fruits, resulting in high levels of fruiting and multiplication (Nerd \& Mizrahi 1997, 2001). High levels of fruit formation represent an efficient strategy for reproduction and for sexual dispersion in populations of Opuntia (Mandujano et al. 1997, 1998b). However, predation of the reproductive and vegetative structures (Hoffmann et al. 1998, Lenzi et al. 2006), low levels of seed germination (Mondragón-Jacobo \& Pimienta-Barrios 2001), and difficulties in seedling establishment and permanence (Mandujano et al. 
1997) can significantly interfere with colonization and the maintenance of population numbers. On the other hand, the seeds of Opuntia spp. can remain dormant but viable in the soil for up to 15 years, forming large seed banks and guaranteeing the perpetuation of the species, as well as substantially contributing to long-term genetic variability within populations (Mandujano et al. 1998b, Montiel \& Montaña 2003, Vilá \& Gimeno 2003).

The fragmentation of the cladodes as well as fruitfall near the mother plant are common but efficient mechanisms for clonal multiplication in Opuntia (Nerd \& Mizrahi 1997, Mandujano et al. 1998a). There is an increase in autogamy generated by the growth clones in these cases, favoring the appearance of homozygotic individuals as well as influencing the dynamics of population establishment and permanence (Mandujano et al. 1998b, Evans et al. 2004, Griffith 2004). The association between sexual and asexual reproduction (clonal multiplication) can reduce the long-term effects of endogamy and favor genetic diversity and the installation, generation, permanence, and distribution of natural populations of different cactus species - as has been demonstrated for Opuntia rastrera F.C.A.Weber. (Mandujano et al. 1998b), Stenocereus gummosus Engelm., and S. eruca Brandegee (Molina-Freaner \& Clark-Tapia 2005).

Opuntia monacantha demonstrates wide geographical distribution and it occurs in a number of Brazilian states as well as some parts of the neighboring countries of Argentina, Paraguay, and Uruguay (Scheinvar 1985, Taylor \& Zappi 2004). $O$. monacantha is an abundant and common colonizing cactus on Florianópolis Island in Southern Brazil and it is often found in the herbaceous-shrub resting $a$ vegetation there (Lenzi 2008) - pioneer plant formations subject to marine influences (Falkenberg 1999).

The present study characterized the reproductive phenology and the predominant reproductive system of $O$. monacantha to determine the adaptive values of both sexual reproduction and clonal multiplication in restinga environments.

\section{MATERIAL AND METHODS}

\section{Study areas}

The study areas were located approximately $32 \mathrm{~km}$ one from the other on Florianópolis Island in the municipality of Florianópolis, in the state of Santa Catarina, Brazil (figure 1): Galheta Beach (area 1) in the Galheta Municipal Park $\left(27^{\circ} 35^{\prime} 28^{\prime \prime} \mathrm{S}\right.$ and $\left.48^{\circ} 25^{\prime} 26^{\prime \prime} \mathrm{W}\right)$, and Armação Beach (area
2) in the Lagoa do Peri Municipal Park (27 $44^{\prime} 38^{\prime \prime} S$ and $48^{\circ} 30^{\prime} 32^{\prime \prime} \mathrm{W}$ ) (figure 1). The vegetation in the study areas was herbaceous-shrub restinga, which, according to Falkenberg (1999), is distributed along three distinct physiognomies: i) beaches and frontal dunes; ii) internal dunes and low plains; and iii) lakes, swamps, and lowland areas. The climate on Florianópolis Island is subtropical humid, type Cfa according to the classification system of Köppen (1948), with average annual temperatures, precipitation, and relative humidity being $22{ }^{\circ} \mathrm{C}, 1400 \mathrm{~mm}$, and $82.14 \%$ respectively. The warmest month, February, has an average temperature of $24.5^{\circ} \mathrm{C}$, while the coldest month, July, has an average temperature of $16.4{ }^{\circ} \mathrm{C}$ (Cecca 1997). Like the other species of the genus Opuntia, O. monacantha has modified stems (cladodes) that are succulent and typically oblong to spatulate-oblong (Scheinvar 1985). According to Nerd \& Mizrahi (2001), cladodes can be classified as terminal (when formed during the previous reproductive cycle) or sub-terminal (those formed in preceeding years, constituting the cladodes preceding the terminal organ). Additionally, there are young cladodes formed in the current year that are still immature. In general, sub-terminal cladodes are united to the main stem as well as to terminal cladodes, thus forming branches distributed over the entire plant. The cladodes and the epidermis of the Opuntia cacti fruits have many areolas - structures with the capacity to differentiate into roots, branches, fruits, spines, glochids, silky hairs, wool, felt, bristles, nectar glands, or flower buds (Scheinvar 1985).

The flowers of $O$. monacantha are radial and shallow, with violet sepals, bright yellow petals, and a light fragrance. Anthesis is diurnal and lasts approximately 10 hours (Lenzi 2008). The flowers are visited by insects such as bees, ants (Hymenoptera), and beetles (Coleoptera). The floral resource offered is pollen; nectar is absent (Lenzi \& Orth 2011). The hundreds of white stamen filaments each have yellow sagittate anthers. The stamens are arranged in a whorl around the style and are positively thigmotropic, retracting at the slightest touch. The anthers become dehiscent in the early morning. The stigma is lobed and remains receptive throughout anthesis. The ovary is inferior, unilocular, and fused to the receptacle (Lenzi 2008).

Fruit and seed dispersal in $O$. monacantha are performed exclusively by the marsupial Didelphis aurita (Wied-Newied, 1826) (Mammalia: Didelphimorphia, Didelphidae), although marine hydrochory represents a potential dispersal agent of the cladodes and fruits of this species within the restinga at various times during the year (Lenzi et al. 2012).

\section{Phenology}

Phenological observations were performed with the population in area 1, from July/2003 to December/2006, observing 40 individual adults. The plants and cladodes that were accompanied were marked with numbered metal tags. The vegetative phenophases were accompanied on a monthly basis in the population by observing 10 individuals more than 


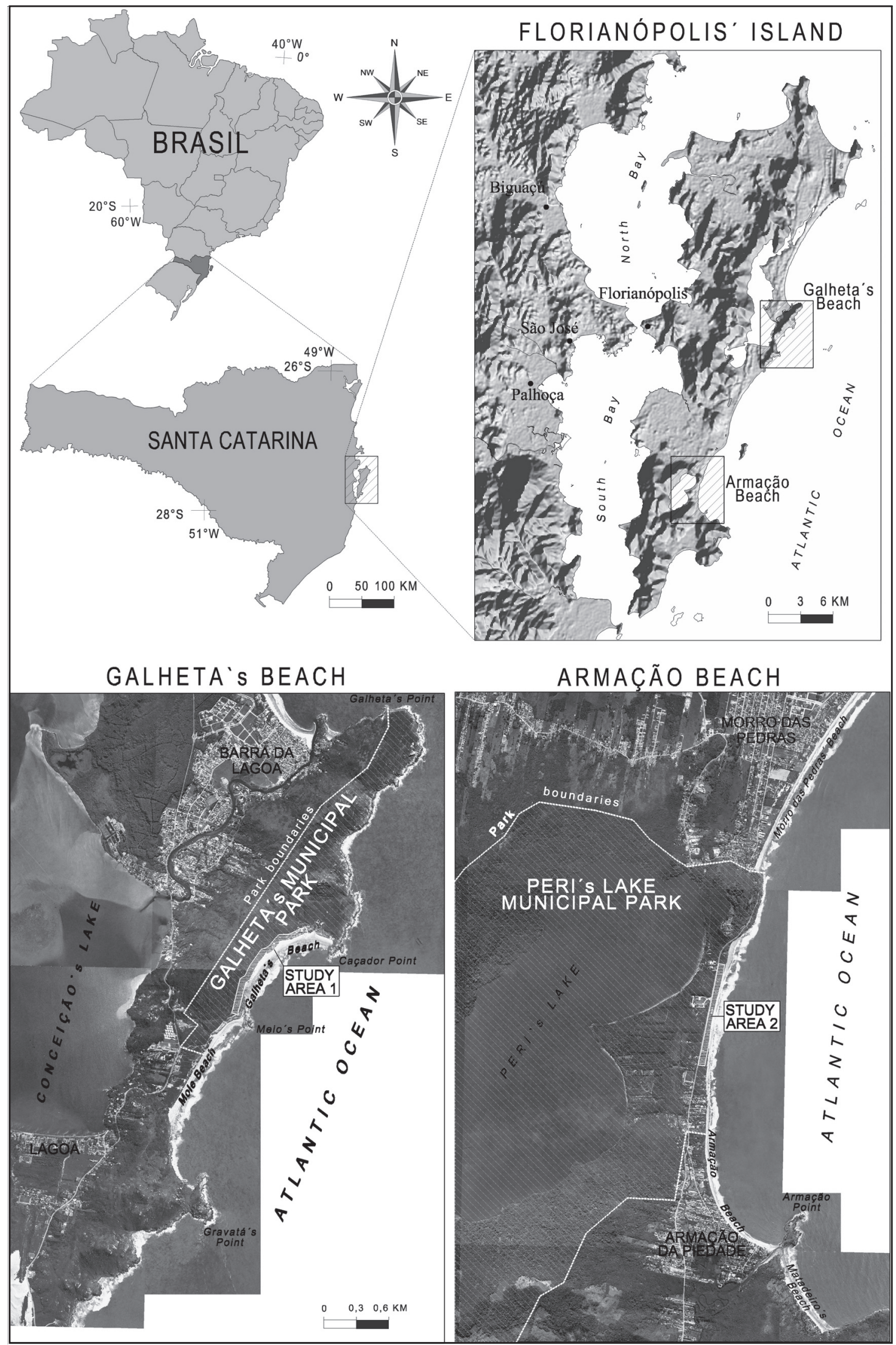

Figure 1. Locations of the study sites in the municipality of Florianópolis, Brazil. Adapted from USGS (2004) and the Atlas do Município de Florianópolis (2004). 
$2 \mathrm{~m}$ tall and had branches with more than three terminal cladodes in (and which did not show signs of damage due to herbivory). Three terminal cladodes were selected on each branch, and the numbers of areolas present were counted as well as the numbers of areola that eventually gave rise to buds. During each monthly census the bud/areola ratio was calculated by dividing the number of buds formed by the numbers of areolas present on the terminal cladodes $(n=30)$.

The reproductive phenophases were evaluated on a weekly basis during three reproductive cycles between 2003 and 2006. We selected 40 adult individuals and randomly chose three branches on each, and then followed four terminal cladodes per branch ( $n=480$ terminal cladodes), evaluating: i) the flowering duration per individual; ii) numbers of flowers produce per individual; iii) numbers of open flowers per individual and per census; and, iv) numbers of open flowers in the population per census. The flowering patterns of this species were determined at the individual and populational levels, following the classification systems of Gentry (1974) and Newstrom et al. (1994).

During each monthly census during each reproductive period (2005/2006) we quantified the floral bud per areola ratio by dividing the number of floral buds formed by the numbers of areolas present on the terminal cladodes $(n=42)$. The development of the fruits formed by the various pollination tests were followed on a monthly basis between October/2004 and October/2006, analyzing the colors, sizes, shapes, and the eventual abscissions of the fruits from the mother plants.

\section{Reproductive systems}

a) The sexual reproductive system - 40 adult plants were used in the pollination tests, considering the terminal cladode as the experimental unit $(n=4)$, and the numbers of flowers $(n=3)$ utilized per terminal cladode as repetitions. One hundred and twenty flowers were used in each pollination experiment as follows: i) free or natural pollination (control) in flowers that were not sacked; ii) spontaneous self-pollination in flowers sacked before anthesis (in waxed paper bags) without any type of posterior manipulation; iii) manual self-pollination of flowers sacked before anthesis and subsequently manually pollinated using pollen grains derived from the same flower; iv) manual cross-pollination of flowers sacked before anthesis and manually pollinated with mixtures of pollen from other flowers (that had likewise been sacked before anthesis) from plants at least $10 \mathrm{~m}$ distant from the test flower; v) apomixis in flowers that had been sacked before anthesis and whose stigmas had been removed using a pair of tweezers (stigma clipped) (Osborn et al. 1988, McFarland et al. 1989, Weiss et al. 1993). After the appropriate experimental manipulations, all of flowers were sacked once again and remained so until completing fruit formation (except in the experiment examining natural pollination). All of the floral buds utilized in the different pollination experiments were marked with small, numbered metal tags tied to the base of the pedicel with colored string. Fruit production among the different pollination experiments were compared using the KruskalWallis test ( $\alpha=5 \%$ probability) on Statix 6.0 software.

The choice of plants, cladodes, and floral buds for the pollination experiments took into account the presence of Cactoblastis cactorum (Lepidoptera: Pyralidae) larva, which, according to Lenzi et al. (2006), can cause negative impacts on the reproductive biology of $O$. monacantha. Plant structures showing any indication of herbivory were not included in the experiments, and plants were constantly monitored for signs of predation.

The Self-Incompatibility Index (SII) (sensu Bullock 1985) was calculated by dividing the percentages of fruit formation from the self-pollination experiments by the percentage of fruit formation resulting from natural crosspollination. We also calculated the Reproductive Efficiency Index (REI), which is the ratio between the percentage of fruits formed by natural pollination (control) and the percentages of fruits formed by manual cross-pollination (Zapata \& Arroyo, 1978).

The mature fruits formed in the different pollination experiments were dissected in order to count their seeds and to evaluate parthenocarpy. Morphometric measurements were also made of the mature fruits formed through natural pollination $(n=66)$, measuring their lengths and diameters (cm), as well as the lengths (mm) of the seeds ( $n=150)$, using digital calipers. The weights of the fruits, the pulp and seeds together, and the seeds alone, were determined using a semianalytical balance. The seeds were separated from the pulp by washing them in running water in a metal sieve.

b) The asexual reproduction system - Clonal multiplication in the field was quantified by calculating the percentage rates of rooting and budding of the cladodes and fruits as well as their mortality rates, using 100 terminal cladodes, 30 sub-terminal cladodes, and 100 mature fruits, during the period between April/2004 and December/2006 in 3 fixed $10 \times 2 \mathrm{~m}$ plots for each evaluation. The structures utilized in the clonal multiplication experiments were monitored for signs of herbivory, as described above.

\section{Seed germination and seedling recruitment}

The germination of seeds from mature fruits (240 days of development) formed in the open-pollination $(n=66)$, manual cross-pollination $(n=49)$, manual self-pollination $(n=10)$, and spontaneous self-pollination $(n=5)$ experiments, were tested as follows: a) Laboratory tests of germination following the methodology described by MondragónJacobo \& Pimienta-Barrios (2001), with the scarification of 150 seeds from each pollination experiment using sulfuric acid $\left(\mathrm{H}_{2} \mathrm{SO}_{4}\right) ; 15$ seeds were then sown into Petri dishes on saturated filter paper liners and maintained in incubators at $\geq 30{ }^{\circ} \mathrm{C}$ with a constant relative humidity $(\geq 78 \%)$ and a 12 hour photoperiod. Germination was evaluated on a weekly basis for 11 months during the year 2006; b) Field tests of 
germination were used to determine if variable environmental factors (such as solar radiation) would provoke differences in seed germination. Four $50 \times 50 \mathrm{~cm}$ plots were established, two of them in soil on an open fissured rock surface (high illumination) and the other two in soil in the plant understory (low illumination). One hundred seeds derived from the natural pollination experiments were sown in each of the four plots; seed germination and seedling growth were accompanied from January/2004 to December/2006.

Spontaneous plant recruitment was determined by monthly counts of the numbers of seedlings resulting from seed bank propagules germinating in 10 fixed $100 \times 2$ m plots in each of the study areas during the period from January/2004 to December/2006. Two plots were established on a fissured rock surface in an area of herbaceous vegetation (near the beach line), and two plots in an area of herbaceous-shrub vegetation (in the stabilized dune zone), and two plots in the understory of an area of shrub vegetation.

\section{RESULTS}

The average number of areolas per terminal cladode $(n=30)$ was $60.3 \pm 8$, with the production of $1.78 \pm 0.7$ new buds every year, yielding a ratio of 0.03 buds/areola per terminal cladode. Once differentiated, the areolas will form only a single bud, and budding occurs between the months of August and May; the greatest production was seen between the months of September and March. After approximately 4 months, the buds attained the shape and size of a terminal cladode, and attained reproductive age near the end of their first year. The emission of floral buds occurs on areolas on terminal and sub-terminal cladodes, as well as on the fruit pedicels. The average number of floral buds per terminal cladode $(n=42)$ was $8.2 \pm 2.4$, with a ratio of 7.3 floral buds/areola per terminal cladode.
The flowering period of this species was from the end of September to mid-January, with a flowering peak of approximately 100 days. During the months October and December; up to nine flowers per individual per day would undergo anthesis (figure 2). Opuntia monacantha demonstrates an annual flowering pattern (sensu Newstrom et al. 1994) and a regular or steadystate type of availability (sensu Gentry, 1974) - with few open flowers per day per individual, but intense flowering at the population level during a long period of time (figure 2).

The immature fruits (up to 30 days of development) maintained the characteristics and dimensions of the floral buds and flowers (with the exception of the corolla, which abscises on the third day after anthesis). After the first month of development there was a noticeable acceleration in fruit growth, and they initiated maturation after approximately 120 days of development and partially acquired a purple color. The fruits completed their maturation after approximately 240 days and acquired an intense violet color. Fruit abscission occurs in two stages; the first is concomitant with maturation (at around 240 days) and extends for up to two months. The second stage involves the fruits that remain attached to the plants for more than a year. During this period these fruits can develop vegetative and floral buds and form chains composed of more than three fruits.

Opuntia monacantha is partially self-compatible, and its preferential pollination mode is xenogamy. The greatest rates of fruit formation and seed germination were obtained from open-pollination (control) and manual cross-pollination experiments (table 1). The fruiting success of flowers submitted to spontaneous

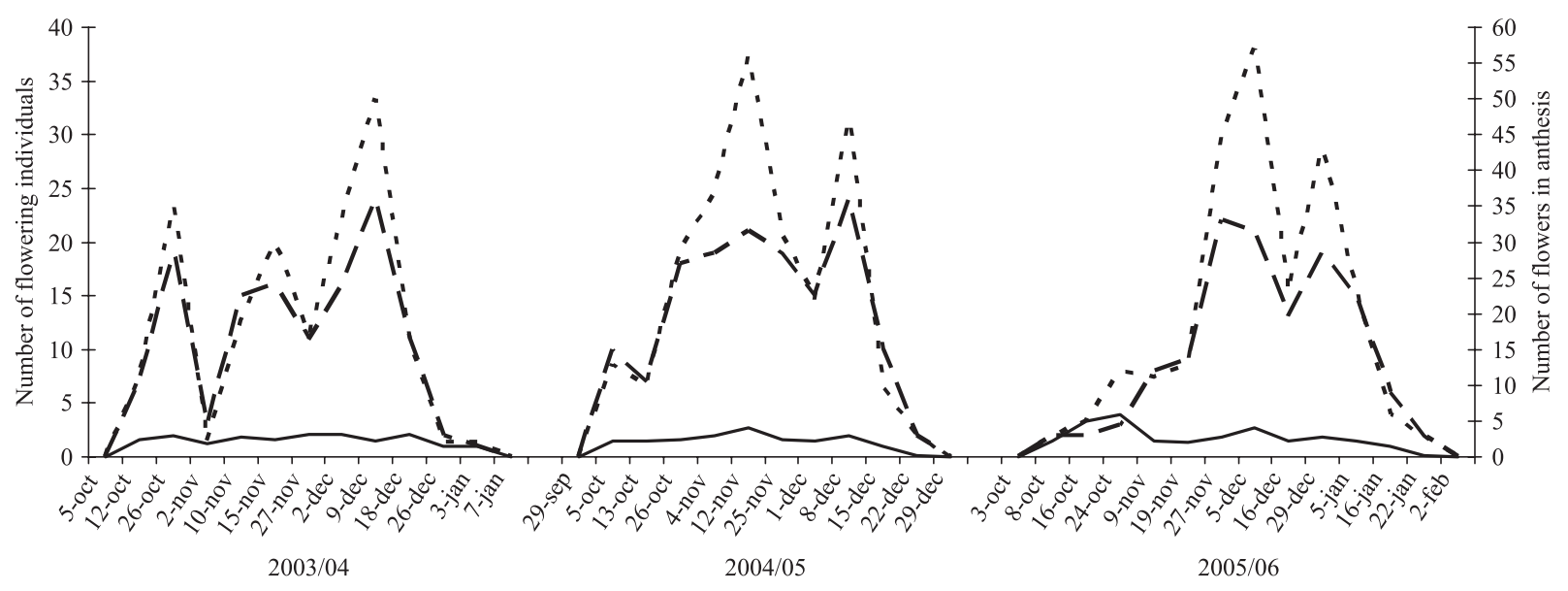

Figure 2. Phenological reproductive patterns of Opuntia monacantha during three assessment periods (2003 to 2006) in the restinga vegetation at Galheta Beach, Florianópolis, SC, Brazil $\left(--=\right.$ flowering individuals day ${ }^{-1} ;-=$ flowers in anthesis individuals ${ }^{-1} ;---=$ flowers in anthesis population ${ }^{-1}$ ). 
self-pollination was low (4\%), indicating that this species requires active pollination agents for significant fruiting. The fruiting success of flowers submitted to manual self-pollination was only moderate $(23 \%)$. The Self Incompatibility Index (SII) of 0.57 indicated that this is a moderately self-sterile species. The rate of fruit formation under natural conditions (control) was 55\%, and was greater than the rate seen with manual crosspollination (41\%) (table 1); the reproductive efficiency was 1.34 (sensu Zapata \& Arroyo 1978).

The abortion of all the fruits arising from tests of apomixis (until 120 days after manipulating the flowers) indicated that this species is not apomictic.

The presence of viable seeds in all of the fruits arising from the different pollination tests indicated that this species is not parthenocarpic.

The average number of seeds $(96.5 \pm 24)$ formed in the fruits resulting from natural pollination $(n=66)$ was greater than the average number of seeds ( $46 \pm 33)$ formed in fruits resulting from manual cross-pollination $(n=49)$, as well as the average number of seeds $(16 \pm 12.2)$ formed in fruits resulting from manual selfpollination $(n=30)$, and the average number of seeds $(4 \pm 1.7)$ formed in fruits resulting from spontaneous self-pollination $(n=5)$. In the same way, different rates of seed formation were observed among the different treatments of manual cross-pollination (75\%), manual self-pollination (26\%), and spontaneous selfpollination (6.4\%) (table 1). The seeds derived from fruits in natural self-pollination tests $(n=66)$ had an average length of $3.80 \pm 0.62 \mathrm{~mm}$ and average weight of $0.81 \pm 0.25 \mathrm{~g}(n=150)$ when physiologically mature (after approximately 240 days). The seeds had a white and thick funicle that completely encircled them and a well-developed perisperm, and they contained a curved embryo.

The highest levels of germination under laboratory conditions (up to 11 months after sowing) were seen with seeds produced by natural pollination $(76 \%)$, followed by $31 \%$ for seeds produced through manual cross-pollination, followed by manual self-pollination $(16 \%)$ and then spontaneous pollination $(5 \%)$ (table 1$)$ indicating that the remaining seeds might be recalcitrant. Under field conditions, the germination rate of seeds formed through natural pollination was only $1.25 \%$, and only five seedlings were observed to emerge in only one plot on a fissured rock surface 11 months after sowing. After 18 months only two seedlings remained, and after 24 months none of the young plants could be found and no new seedlings were observed in the plots - resulting in a $100 \%$ seedlings mortality rate. We were unable to observe any predation of the seedlings during our observations. No spontaneous seedlings were observed germinating or growing in the field plots during the study period.

The terminal cladodes $(n=100)$ demonstrated high rates of rooting (95\%) and budding (98\%) and a low mortality rate $(4 \%)$. Similarly, the fruits $(n=100)$ demonstrated high rates of rooting $(100 \%)$ and budding $(96.8 \%)$ and a low mortality rate $(1.5 \%)$. On the other hand, the sub-terminal cladodes $(n=30)$ had lower rates of rooting $(45.5 \%)$ and budding $(48.5 \%)$ and a higher mortality rate $(28.5 \%)$. When terminal and sub-terminal cladodes (whether linked or not to the mother plant) touch the ground they can produce roots and vegetative buds or floral buds. It is not unusual to see groups of young plants united to the remains of cladodes and fruits near a presumed mother-plant.

Table 1. Fruit set (\%) of Opuntia monacantha during three development periods following anthesis in different pollination tests ( $n=120$ flowers, per test), and the germination of their seeds ( $n=150$, per test) after 240 days of development, in Florianópolis, SC, Brazil.

\begin{tabular}{|c|c|c|c|c|}
\hline \multirow{2}{*}{ Test } & \multicolumn{3}{|c|}{ Development period (days) } & \multirow{2}{*}{$\begin{array}{l}\text { Seed germination } \\
(\%)\end{array}$} \\
\hline & 30 & 120 & 240 & \\
\hline Open-pollination (control) & $98 \mathrm{Aa}^{*}$ & $90 \mathrm{Ab}$ & $55 \mathrm{Ac}$ & 76 \\
\hline Manual cross-pollination & $99 \mathrm{Aa}$ & $85 \mathrm{Ab}$ & $41 \mathrm{Ac}$ & 31 \\
\hline Spontaneous self-pollination & $86 \mathrm{Aa}$ & $64.2 \mathrm{Bb}$ & $4 \mathrm{Cc}$ & 5 \\
\hline Manual self-pollination & $88 \mathrm{Aa}$ & $51 \mathrm{Bb}$ & $23 \mathrm{Bc}$ & 16 \\
\hline Apomixis & $93 \mathrm{Aa}$ & $17 \mathrm{Cb}$ & - & - \\
\hline
\end{tabular}

*Different lowercase letters in the same line indicate significant differences between the pollination tests during the different evaluation periods. Different uppercase letters in the same column indicate significant differences between pollination tests during each evaluation period. Kruskal-Wallis Test $(\alpha=5 \%$ probability) 


\section{DISCUSSION}

The phenological patterns of $O$. monacantha observed in the present study corroborated those reported by Scheinvar (1985) and demonstrated that plants of this species produce vegetative and floral buds in the Austral spring and summer seasons (between October and December), with long periods of fruit development and delayed dispersal - resulting in overlapping vegetative and reproductive phenophases. The maturation of Opuntia fruits generally takes quite a long time, occurring during the entire year between four and 428 days after anthesis; the first fruits that abscise are actually aborted flowers (Reyes-Agüero et al. 2006). Nerd \& Mizrahi (2001) noted that flowering extends for a number of weeks in O. ficus-indica (L.) Mill. and these plants can simultaneously initiate the differentiation of areolas, flowers, and young fruits. Our ability to associate the period of activity of a given phenophase with its intensity will not only facilitate the analysis and interpretation of the phenological behavior of a given species but can play an important role in studies of plant-animal interactions - for it combines information about synchrony and resource availability (Bencke \& Morellato 2002).

Regular or steady-state flowering is associated with bees with trap-line foraging strategies (sensu Gentry 1974). Siqueira-Filho \& Machado (2001) noted that this flowering strategy consists of producing just a few flowers per day during a long period of time, which favors random cross-pollinations between individuals of different groups. A study by Lenzi \& Orth (2011) with $O$. monacantha in restinga areas on Florianópolis Island demonstrated that the flowers of this species are frequently visited by different bee guilds and indicated that Cephalocolletes isabelae Urban, 1995 (Colletidae) is an oligolectic floral visitor and the principal pollinator of O. monacantha.

The preferred reproductive system of $O$. monacantha was found to be allogamy but it demonstrates moderate pollen self-compatibility. Studies of the reproductive biology of other species of Opuntia have indicated xenogamy as their preferential pollination system (Osborn et al. 1988, McFarland et al. 1989, Nerd \& Mizrahi 2001), although other studies have indicated the concomitant presence of moderate self-compatibility (Pimienta-Barrios 1994, Nerd \& Mizrahi 1997, Schlindwein \& Wittmann 1997) and pseudocleistogamy (Pimienta-Barrios 1994, Nerd \& Mizrahi 1997). Selfcompatibility may represent an adaptive advantage for species occupying new environments, especially in areas where pollinators are rare or very specific. As such, selfpollination would be favored in situations with limited floral visitation or when the visitors are not well-adapted to their floral morphology; cross-pollination would be advantageous when the reproductive capacity of the plant was not limited by a scarcity of pollinators (Richards 1997).

Species of the genus Opuntia demonstrate mixed systems of crossings, with the levels of autogamy and xenogamy differing among species and populations - and even during a given flowering season. O. brunneogemmia (F. Ritter) C. Schlindwein and O. viridirubra (F. Ritter) P. J. Braun \& Esteves, which grow in Southern Brazil, are self-compatible ( $52 \%$ of their seeds are fertile), but the highest rates of fecundation of the species occur through cross-pollination (84-100\%) (Schlindwein \& Wittmann 1997). A population of O. anacantha var. retrorsa (Speg.) R. Kiesling in the Chaco region of Argentina was found to have a high rate of self-pollination $(61.1 \%)$ while another population was observed to have a higher rate of cross-pollination. $O$. lindheimeri Engelm. growing in Texas (USA) is essentially allogamic at the beginning of anthesis when the stigma is taller than the anthers, but by the end of anthesis the flowers become self-compatible as the anthers reach the same height as the stigma (ReyesAgüero et al. 2006).

The high rates of rooting and budding of the cladodes of $O$. monacantha indicate a very high investment in asexual reproduction. Additionally, the fruits are wrapped in tissue derived from the stem - making them clonal propagules with the capacity to root and bud (Scheinvar 1985, Lenzi et al. 2012). It is therefore assumed that greater fruit production would also result in a greater potential for vegetative propagation, with resulting increases in clonal populations. Additionally, cladodes and fruits tend to fall near the mother plant, thus favoring the formation of clumps of plants that will increase the numbers of available flowers, and therefore pollination and endogamy levels.

The simultaneous occurrence of both sexual and asexual reproduction is considered more advantageous than a single mode of replication because together they confer high adaptive values under very adverse and competitive situations (Cruden 1977, Faegri \& van der Pijil 1979). The high-frequency of mixed reproduction systems in the genus Opuntia can help maintain specific genetic combinations, perpetuate hybrids, and aid in developing dense populations with high capacities for colonizing new areas (Rebman \& Pinkava 2001). Abrahamson (1980) noted that the balance between asexual and sexual reproduction directly influences plant 
population densities. In this sense, sexual reproduction complements clonal multiplication in $O$. monacantha, as the latter represents a secure form of growth and persistence of local populations while the rare events of plant establishment through sexual reproduction will guarantee increasing genetic variation in the population.

Opuntia monacantha is not an apomictic species. According to Reyes-Agüero et al. (2006), apomixis is rare in Opuntia, although it has been reported in $O$. aurantiaca Lindl., $O$. dillenii Haw., O. leucantha Link. \& Otto, and O. tortispina Engelm. \& J. M. Bigelow. In these species, the apomictic seeds are almost always of nucelar origin (sporophytic agamospermy) and do not demonstrate abnormalities (Mondragón-Jacobo \& Pimienta-Barrios 2001). Osborn et al. (1988), on the other hand, reported that the seeds of $O$. polyacantha Haw. and $O$. phaeacantha Engelm. that arose through xenogamy demonstrated greater viability than those produced by other forms of pollination. The same situation appears to apply to $O$. monacantha, which demonstrated high levels of seed production and germination arising from natural pollination regimes and manual crosspollination experiments. Additionally, most of the fruits generated from self-pollination experiments aborted, and these abortion rates were higher than those observed in cross-pollinations. These results suggest that the abortion of fruits formed through spontaneous or manual self-pollination may represent situations of delayed incompatibility or endogamic depression, suggesting the predominance of endogenous pollen flux between flowers of different clones.

The absence of parthenocarpy in $O$. monacantha, as observed in the present study, corroborates other studies of species of this same genus (Nerd \& Mizrahi 2001) and suggests that parthenocarpy is not very common in this group. Although no natural or commercial populations of Opuntia are known to demonstrate parthenocarpy, some of the fruits found in natural stands of these plants contain aborted seeds (Weiss et al. 1993). The causes of these natural abortions are still unknown, but it has been established that fruit size and development depends on the numbers of fertilized and aborted seeds (Nerd \& Mizrahi 1997, 2001).

Opuntia monacantha has very small, numerous, and hard seeds. Reinhardt et al. (1999) and Reyes-Agüero et al. (2006) noted that these characteristics are quite common in Opuntia seeds and are associated with the impermeability of the tegument, funicular hardening, and with their capacity to survive long periods of dormancy (up to 15 years or more). The high germination rates observed after scarifying the seeds in sulfuric acid demonstrated that the seeds are recalcitrant, but this treatment did not reveal any necessity for overcoming dormancy in seeds collected in the first year after their production (as has been seen in other species of Opuntia) (Reyes-Agüero et al. 2006). Montiel \& Montaña (2003) observed that the dormancy of $O$. rastrer $a$ seeds is related to the formation of large seed banks that help guarantee long-term survival, regeneration, and genetic variability. Reinhardt et al. (1999) associated to the invasive capacity of some species of Opuntia with the prolonged natural dormancy of their seeds. On the other hand, Montiel \& Montaña (2003) and Vilá \& Gimeno (2003) suggested that there is a compensatory relationship in some species of Opuntia between the formation of seed banks with low germination viability and strong predatory pressures exerted by birds, rodents, and ants. Additionally, Mandujano et al. (1997) noted the importance of endozoochory to the successful germination of $O$. rastrera seeds - which demonstrate naturally low rates of seedling recruitment (approximately one juvenile plant for every 3 million seeds produced).

According to Mandujano et al. (1998b), the juvenile plant is most vulnerable stage in the lifecycle of Opuntia, and their establishment in desert environments is often limited to sites shaded by perennial "nursery plants" and dependent on their more favorable environmental conditions. Hughes et al. (2011) reported that seedlings of Melocactus ernestii subsp. ernestii in the Caatinga biome in northeastern Brazil principally emerge in association with adult and juvenile individuals of the same species. The preferential association of germination and seedlings development with certain species of established plants in environments with stark climatic extremes appears to be fundamental to the recruitment of new individuals of a number of cactus species (Mandujano et al. 1998b, Hughes et al. 2011). Another factor that should be considered is that the only seedlings of $O$. monacantha observed growing in the field were derived from seeds planted in crevices on rock outcrops without any obvious association with "nursery plants". Vargas \& Gonzalez (1992) reported lower mortality rates of O. streptacantha Lem. seedlings in rock outcrops with grassy vegetation than in areas without any vegetation cover, but Hughes et al. (2011) suggested that micro-sites initially efficient in trapping seeds and promoting their germination are not necessarily the best sites for seedling establishment in M. ernestii.

In spite of the fact that clonal multiplication is an efficient mechanism for occupying new sites, principally those that have suffered disturbances, temporal 
overlapping with sexual reproduction can have long-term consequences for cactus species populations, including increasing homozygosity and endogamy (Mandujano et al. 1998b). Molina-Freaner \& Clark-Tapia (2005) related losses of genetic variability in populations of the cactus species Stenocereus gummosus and S. eruca to their excessive reliance on asexual reproduction. These authors noted that the combination of sexual reproduction and clonal recruitment could favor the long-term regeneration of populations even as increases in the soil seed bank would provide new genetic combinations.

Acknowledgments - The authors would like to thank the reviewers for their suggestions and corrections and M.Sc. Angelo Martins Fraga for elaborating the map of the study area. The first author was supported by a study grant provided by Capes (Coordenação de Aperfeiçoamento de Pessoal de Nível Superior).

\section{REFERENCES}

Abrahamson WG. 1980. Demography and vegetative reproduction. In Demography and evolution in plant populations (OT Solbrig, ed.). Blackwell, Oxford, p.89106.

Araújo DSD, Lacerda LD. 1987. A natureza da restinga. Ciência Hoje 6:42-48.

Atlas do Município de Florianópolis. 2004. Prefeitura Municipal de Florianópolis e Instituto de Planejamento Urbano de Florianópolis, Florianópolis.

Bencke CSC, Morellato LPC. 2002. Comparação de dois métodos de avaliação da fenologia de plantas, sua interpretação e representação. Revista Brasileira de Botânica 25:269-275.

Bullock SH. 1985. Breeding systems in the flora of a tropical deciduous forest. Biotropica 17:287-301.

CECCA - Centro de Estudos Cultura e Cidadania. 1997. Uma cidade numa ilha. Editora Insular, Florianópolis.

Cruden RW. 1977. Pollen-ovule ratio: a conservative indicator of breeding system in flowering plants. Evolution 31:3236.

Evans LS, Imson GJ, Kim JE. 2004. Relationships between numbers of stem segments on longest stems, retention of terminal stem segments and of establishment and detached terminal stem segment for 25 species of Cylindropuntia and Opuntia (Cactaceae). Journal of the Torrey Botanical Society 13:195-203.

Faegri K, Van Der Pijil L. 1979. The principles of pollination ecology. Pergamon Press, New York.

Falkenberg DB. 1999. Aspectos da flora e da vegetação secundária da restinga de Santa Catarina, sul do Brasil. Insula 28:1-30.

Gentry AH. 1974. Flowering phenology and diversity in tropical Bignoniaceae. Biotropica 6:64-68.
Griffith PM. 2004. The origins of an important cactus crop, Opuntia ficus-indica (Cactaceae): new molecular evidence. American Journal of Botany 91:1915-1921.

Hoffmann JH, Moran VC, Zeller DA. 1998. Evaluation of Cactoblastis cactorum (Lepidoptera: Phycitidae) as a Biological Control Agent of Opuntia stricta (Cactaceae) in the Kruger National Park, South Africa. Biological Control 12:20-24.

Hughes FM, de La Cruz M, Romão RL, Castro MS. 2011. Dinâmica espaço-temporal de Melocactus ernestii subsp. ernestii (Cactaceae) no Nordeste do Brasil. Revista Brasileira de Botânica 34:389-402.

Klein AS, Citadini-Zanette V, Santos R. 2007. Florística e estrutura comunitária de restinga herbácea no município de Araranguá, Santa Catarina. Biotemas 20:15-26.

Köppen W. 1948. Climatologia. Fondo de Cultura Económica, México.

Lenzi M. 2008. Biologia reprodutiva de Opuntia monacantha (Willd.) Haw. (Cactaceae) nas restingas da Ilha de Santa Catarina, sul do Brasil. Doctoral thesis, Universidade Federal de Santa Catarina, Florianópolis.

Lenzi M, Orth AI. 2011. Visitantes florais de Opuntia monacantha (Cactaceae) em restingas de Florianópolis, SC, Brasil. Acta Biologica Paranaense 40:19-32.

Lenzi M, Soares J, Orth AI. 2006. Herbivoria de Opuntia monacantha (Willd.) Haw. (Cactaceae) por Cactoblastis cactorum (Lepidoptera: Pyralidae) em restingas da Ilha de Santa Catarina, sul do Brasil. Biotemas 19: 35-44.

Lenzi M, Graipel ME, Matos JZ, Fraga AM, Orth AI. 2012. Dispersão zoocórica e hidrocórica marítima de Opuntia monacantha (Willd.) Haw. (Cactaceae). Biotemas 25:47-53.

Mandujano MC, Golubov J, Montaña C. 1997. Dormancy and endozoochorous dispersal of Opuntia rastrera seeds in the southern Chihuahuan Desert. Journal of Arid Environments 36:259-266.

Mandujano MC, Golubov J, Montaña C, Mauseth JD, Plemons-Rodrigues BJ. 1998a. Evolution of extreme xenomorphic characters in woody: a study of nine evolutionary lines in Cactaceae. American Journal of Botany 85:209-218.

Mandujano MC, Montaña C, Méndez I, Golubov J. 1998b. The relative contributions of sexual reproduction and clonal propagation in Opuntia rastrera from two habitats in the Chihuahuan desert. Journal of Ecology 86:911-921.

Mcfarland JD, Kevan PG, Lane MA. 1989. Pollination biology of Opuntia imbricata (Cactaceae) in southern Colorado. Canadian Journal of Botany 67:24-28.

Molina-Freaner F, Clark-Tapia R. 2005. Clonal diversity and allelic relationship between two closely related species of columnar cacti from the Sonoran Desert: Stenocereus eruca and Stenocereus gummosus. International Journal of Plant Sciences 166:257-264. 
Mondragón-Jacobo C, Pimienta-Barrios E. 2001. Multiplicação. In Agroecologia, cultivo e usos da palma-forrageira (Organização das Nações Unidas para a Alimentação e Agricultura - FAO/Serviço Brasileiro de Apoio às Micros e Pequenas Empresas/SEBRAE, eds.). SEBRAE/Paraiba, João Pessoa, p.65-71.

Montiel S, Montaña C. 2003. Seed bank dynamics of the desert cactus Opuntia rastrera in two habitats from the Chihuahuan Desert. Plant Ecology 166:241-248.

Negrón-Ortiz V. 1998. Reproductive biology of a rare cactus, Opuntia spinosissima (Cactaceae), in the Florida Keys: why is seed set very low? Sex Plant Reproduction 11:208-212.

Nerd A, Mizrahi Y. 1997. Reproductive biology of cactus fruit crops. Horticultural Reviews 18:321-347.

Nerd A, Mizrahi Y. 2001. Biologia reprodutiva. In Agroecologia, cultivo e usos da palma-forrageira (Organização das Nações Unidas para a Alimentação e Agricultura - FAO/Serviço Brasileiro de Apoio às Micros e Pequenas Empresas/SEBRAE, eds.). SEBRAE/ Paraiba, João Pessoa, p.49-57.

Newstrom LE, Frankie GW, Baker HG. 1994. New classification for plant phenology based on flowering patterns in lowland tropical rain forest trees at La Selva, Costa Rica. Biotropica 26:141-159.

Osborn MM, Kevan PG, Lane MA. 1988. Pollination biology in Opuntia polyacantha and Opuntia phaeacantha (Cactaceae) in southern Colorado. Plant Systematics and Evolution 159:85-94.

Pimienta-Barrios E. 1994. Prickly pear (Opuntia spp.), a valuable crop for the semi arid lands of Mexico. Journal of Arid Environments 28:1-11.

Rebman JP, Pinkava DJ. 2001. Opuntia cacti of North America - an overview. Flower Entomology 84:474-483.

Reinhardt CF, Rossouw L, Thatcher L, Lotter WD. 1999. Seed germination of Opuntia stricta: implications for management strategies in the Kruger National Park. South African Journal of Botany 65:295-298.

Reyes-Agüero JA, Aguirre RJR, Valiente-Banuet A. 2006. Reproductive biology of Opuntia: a review. Journal of Arid Environments 64:549-585.
Richards AJ. 1997. Plant breeding systems. Chapman \& Hall, London.

Scheinvar L. 1985. Cactáceas. Flora Ilustrada Catarinense, Herbário Barbosa Rodrigues, Itajaí.

Scherer A, Maraschin-Silva F, Baptista LRM. 2005. Florística e estrutura do componente arbóreo de matas de Restinga arenosa no Parque Estadual de Itapuã, RS, Brasil. Acta Botanica Brasilica 19:717-726.

Schlindwein C, Wittmann D. 1997. Stamen movements in flowers of Opuntia (Cactaceae) favour oligolectic pollinators. Plant Systematics and Evolution, 204:179193.

Siqueira-Filho já, Machado ICS. 2001. Biologia reprodutiva de Canistrum aurantiacum E. Morren (Bromeliaceae) em remanescente da Floresta Atlântica, Nordeste do Brasil. Acta Botanica Brasilica 15:427-443.

Soffiatti P, Angyalossy V. 2003. Stem anatomy of Cipocereus (Cactaceae). Bradleya 21:39-48.

Suguio K. 2003. Geologia sedimentar. Edgard Blücher, São Paulo.

Taylor N, Zappi D. 2004. Cacti of Eastern Brazil. Royal Botanic Gardens, Kew.

USGS. 2004. Reprocessing by the $\operatorname{GLCF}(1,3,30)$, Arc Second SRTM Elevation, Reprocessed to GeoTIFF. Version 1.0, College Park, Maryland.

Vargas MMC, González EM. 1992. Habitat heterogeneity and seed dispersal of Opuntia streptacantha in nopaleras of central Mexico. Southwestern Naturalist 37:379-385.

Vilá M, Gimeno, I. 2003. Seed predation of two alien Opuntia species invading Mediterranean communities. Plant Ecology 167:1-8.

Weiss J, Nerd A, Mizrahi Y. 1993. Vegetative parthenocarpy in the cactus pear Opuntia ficus-indica (L.) Mill. Annals of Botany 72:521-526.

Wessels AB, Swart E. 1990. Morphogenesis of the reproductive bud and fruit of the prickly pear (Opuntia ficus-indica (L.) Mill. cv. Morado). Acta Horticulture 275:245-253.

Zapata TR, Arroyo MTK. 1978. Plant reproductive ecology of a secondary deciduous tropical forest in Venezuela. Biotropica 10:221-230. 